\title{
Reproduction and the Welfare State: Notes on Norwegian Biopolitics
}

\author{
Victor Lund Shammas* \\ Work Research Institute \\ OsloMet \\ Email: contact@ victorshammas.com \\ *corresponding author

\section{Tony Joakim Sandset} \\ Centre for Health Sciences Education, Faculty of Medicine \\ University of Oslo \\ Email: t.j.sandset@medisin.uio.no
}

\begin{abstract}
Norway has long been considered to be a bastion of social democracy due to its strong, protective, decommodifying welfare state. However, with the recent rise of neoliberalism and right-wing populist politics across the West, this Northern European society has gradually shifted from Keynesian Fordism to a moderate form of neoliberalism. This political-economic pivot has also resulted in a transformation of what Foucault termed biopolitics: a politics concerned with life itself. In early 2019, leading politicians in Norway's centre-right coalition government placed the problem of the declining fertility rate on the national agenda and framed the problem of biological reproduction in ways particular to their political-ideological perspectives. The Conservative Party discussed reproduction in terms of producerism, or the problem of supplying the welfare state with labouring, tax-paying citizens. The Progress Party emphasised ethnonational exclusion, engaging in racial denigration with the aim to ensure the reproduction of 'ethnic Norwegians'. The Christian Democrats highlighted a conservative Christian 'right to life' topos amidst growing secularisation and pluralism. All three parties signalled a turn from traditional social-democratic ideologies. Neoliberalism has proven to be malleable, able to fuse with a wide
\end{abstract}


range of biopolitical programmes including moral exhortations, ethnonational exclusion and religious discourse to approach the problem of reproduction. However, this post-social-democratic approach generally is unwilling to provide material security through large-scale social expenditures and universal welfare institutions, preferring instead to address the 'hearts and minds' of the populace. Consequently, the fundamental cause of sub-replacement fertility-the gradual proliferation of ontological insecurity—remains unaddressed.

Keywords: biopolitics, Foucault, ethno-nationalism, social democracy, neoliberalism, fertility

\section{Introduction}

On the first day of 2019, Norwegian Prime Minister Erna Solberg used her annual New Year's address to exhort the population to reproduce. Doing so, the prime minister said, was important to increase the Norwegian fertility rate and counteract what she perceived as a demographic threat to the very survival of the welfare state. 'The wheels of our society keep turning because adults look after children', Prime Minister Solberg (2019) said. 'And those who are able to work ensure that the elderly can be cared for'. However, the prime minister believed that in the near future, 'we will encounter problems with this model. Norwegians are having fewer children. In order to maintain our population, the average birth rate needs to be a little over two children per woman. Today, the average birth rate is just 1.6. This means ... there will be fewer young people to bear the increasingly heavy burden of the welfare state. Norway needs more children!'1

\footnotetext{
1 This essay offers an overview of a series of interlinked political developments that unfolded in Norway in the first three months of 2019. This essay does not offer an exhaustive account of the media coverage of these developments but instead provides a schematic for reading and interpreting certain key statements by central political actors. While media sociology offers much to formalised journalistic analysis (see, e.g., Benson \& Neveu, 2005), this essay extracts media statements and views them as signposts of a series of political-ideological routes taken by various Norwegian political actors in recent years. The analysis draws on the authors' close reading of the unfolding media debates. The selection followed a snowball sampling strategy in which the authors followed the ensuing debate on fertility rates as a political issue. The analysis consists of an intertextual reading influenced by literary studies, focusing on the intertextual, heteroglossic connections between the ongoing political debates.
} 
This rousing natalist rhetoric drew on a topos long familiar to mainstream political scientists, demographers and political economists: the problems presumed to be posed by the aging population for the state's capacity to provide adequate services, particularly the alleged imbalance between working-age taxpayers and increasingly long-lived pensioners drawing on costly (state-run) retirement plans and healthcare services in an unsustainable fashion. The Norwegian fertility rate stood at 2.50 children per woman in 1970 but declined to 1.62 by 2017 (Statistics Norway, 2018). The prime minister's homily on fertility instantiated what might be called a producerist biopolitics, aimed at creating what she described as a 'sustainable welfare society'. However, crucially, her argument relied on a particular framing of demographic necessity that was, as we shall see, not entirely unproblematic.

Ten days after Solberg's speech, Per-Willy Amundsen, a leading politician in the populist right-wing Progress Party-the prime minister's governing coalition partner-threw a counterpunch. His reproach more narrowly targeted Norway's immigrant population, railing against its allegedly excessive fecundity. 'I'm interested in having a sustainable population composition', Amundsen said (Jensen, 2019). He then claimed that 'ethnic Norwegians have a sinking birth rate. Like [Prime Minister] Erna Solberg, I believe we have to do something about it. But the solution is not a larger immigrant population. On the contrary, we need to ensure that the ethnically Norwegian population is maintained' (Jensen, 2019). Amundsen-a member of a party that, since its founding in the 1980s, had criticised this northern European country's immigration policies as too liberal-claimed that Solberg's diagnosis, although generally correct, had overlooked a crucial ethno-racial component. Certainly, fertility was low among 'native' Norwegians, but immigrants compensated for this lack through uncontrollable fertility-fecundity run amok. To a party with a stated aim to maintain the demographic majority position of 'ethnic Norwegians', this trend constituted a slow national-cultural act of self-destruction, a glacial replacement of ethnonational insiders by a series of ethno-racial Others.

Amundsen's proposed solution involved cutting state child benefits to families with four or more children. In Norway, families are paid a monthly allowance known as barnetrygd (child benefits), intended to subsidise the costs of childrearing. Although the allowance is a universal welfare policy and is not means-tested, it remains modest, providing on average a scanty $8 \%$ of a singleparent household's earnings (Norsk Telegrambyrå, 2018). In other words, the allowance makes a non-negligible but far from significant contribution to the fiscal well-being of families with children. Amundsen insinuated that immigrants beget offspring as a means to draw these (relatively insignificant) cash transfers 
from the state, so capping payments at three children would remove this incentive for the so-called 'foreign' populations to reproduce, the Norwegian Progress Party argued. Amundsen seized the opportunity offered by Solberg's natalist New Year's address to expound on what he and his party considered to be a demographic threat to Norwegian culture. His proposed cap on payments to households with three children would 'first and foremost be of significance to large immigrant families that have a large number of children, where birth production is high' (Jensen, 2019). This phrase 'birth production' (fødselsproduksjon in Norwegian) suggested a cold, rational, machinic fertility, a relentless and almost mechanical force. In particular, Amundsen claimed, 'Somalis ... have a far greater number of births than ethnic Norwegians do' (Jensen, 2019). The problem, Amundsen mused, was not inadequate fertility itself, as the prime minister had claimed, but, instead, an ethno-racially and ethno-nationally skewed fertility pattern: too many children on 'their' side, too few children on 'his' own side.

Finally, almost three weeks after the New Year's Address leading Christian Democrat Kjell Ingolf Ropstad, a member of Solberg's governing coalition, entered the debate. As stout opponents of liberal abortion lawsparticularly the right to selective or multifetal reduction, a procedure to lower the number of foetuses in multiple pregnancies-Ropstad and the Christian Democrats drew the ire of the country's pro-choice movement for opposing legislation permitting multifetal reduction measures. 'If you're able to bear one [child], you can manage two [children]', Ropstad said during a televised debate (Aftenposten, 2019), drawing wide rebukes from liberal commentators and Norwegian centrists and leftists alike. His comments were read as an undue encroachment on women's right to self-determination and an attack on the safety of women and unborn foetuses. ${ }^{2}$ Ropstad later backed down from his comments and apologised for any offense he might have caused: 'My point is that we need to ease the way for these families. If it is the case that you really want to give birth to one child, then we as a society should ease the way for you to be able to give birth to two children', the Christian Democrat said (Aftenposten, 2019).

${ }^{2}$ Multiple pregnancies carry more risk than single gestations; in the words of one medical review, they 'constitute significant risk to both mother and fetuses' (Norwitz, Edusa \& Park, 2005, p. 338). 


\section{Contextualising Biopolitics}

Why do these incidents matter? They illustrate the tensions and contradictions likely to exist within all coalition governments, typically held together by uneasy alliances and truces that often threaten to splinter and collapse. Since January 2019, Norway has been governed by a coalition composed of the centre-right Conservative Party, right-wing Progress Party, centrist Liberal Party and traditionalist Christian Democratic Party. These parties are united in numerous political-economic concerns, including what can be broadly termed a neoliberal agenda favouring lower taxes and social spending, but they also exhibit significant cleavages. Fertility is merely one significant flashpoint.

Moreover, the natalist question in Norway raises more general issues of statecraft concerning what it means to occupy a position of biopolitical power in the late-modern era. The political figureheads discussed play on fertility as a means to mount a defence of the welfare state but, in various ways, also express contrasting and at times divergent political positions. Their focus on fertility can be helpfully analysed using Foucault's $(1990,2008)$ well-known concept of biopolitics, which, as multiple scholars have pointed out, is a thorny and occasionally vague concept within his wider oeuvre (Dean, 2013; Lemke, Casper \& Moore, 2011). Foucault's (2003) foundational definition, though, is reasonably clear: 'Biopolitics deals with the population, with the population as a political problem, as a problem that is at once scientific and political, as a biological problem and as power's problem' (p. 245). From this perspective, biopolitics is concerned with the figure of the population more than the individual body. A politics operating at the scalar level of the population shifts attention to a diverse set of objects that must be regulated, monitored and normalised in the policymaking process. For Foucault (1990), these objects of concern include, inter alia, life expectancy, health, marriage age, birth rates and mortality rates.

By focusing on these issues, we show how fertility rates have become a rhetorical site where the three coalition partners within the Norwegian government use demographic trends to promote their specific brand of politics. ${ }^{3}$ Foucault's notion of biopolitics can be a useful analytical tool to highlight certain trends in contemporary Norwegian politics. We do not offer a comprehensive analysis of the Norwegian political landscape as such; instead, we assess how

\footnotetext{
${ }^{3}$ The Christian Democrats joined Solberg's coalition government on 22 January 2019 at the peak of the unfolding debates discussed.
} 
these three political parties use fertility as a rhetorical device to frame their respective brands of politics. Moreover, we argue that the construction of fertility is entangled with the trope of 'defending the welfare state'. Each party deploys fertility as a means to bolster the concept of 'the welfare state', even as this entity comes to be understood along divergent ethical, political and economic lines.

This article discusses these contradictory uses of biopolitics within the context of a social-democratic welfare state transitioning into a (moderate) form of a neoliberal political economy (see, e.g., Shammas, 2018) in which the three parties discuss and mobilise ethnonationalism and individual responsibility to raise public, moral and political support for their political agendas. Rather than assigning blame for various social ills to exponents of neoliberalism, these politicians strategically use what Adorno (2000, p. 48) called 'social blinding'the misattribution of causal factors to non-causal forces, directing 'resentment not against the causes but against those who really or supposedly profit from them'-to direct attention away from the curtailment of the welfare state and the roll-back of a protective, decommodifying political economy. As the retrenchment of the welfare state progresses, the relevance of these biopolitical concerns will only likely grow.

The prime minister's New Year's Address clearly articulates individualised responsibility to correct falling fertility rates. In an attempt at levity, the Norwegian prime minister quips that she does not 'need to tell anyone how' to raise the fertility rate and that the government is not 'not thinking of issuing any orders' (Solberg, 2019). Solberg thus excludes any attempts at structural interventions, for example, in labour and housing markets that might ease the issues facing young couples considering bringing children into the world. In contrast, the Progress Party predicates its position on ethnonationalist collectivism, suggesting antagonistic relationships between diverse ethnic groups. The tensions between these uneasy partners-the Conservative Party's individualisation and the Progress Party's ethnonationalism-illustrate the emerging entanglement of neoliberalism with ethnonationalism in this era.

In Capital, Marx (1976) proposed that biological reproduction remains a fundamental political problem of capitalism: 'The labour-power withdrawn from the market by wear and tear, and by death, must be continually replaced by, at the very least, an equal amount of fresh labour-power' (p. 275). Without the biological reproduction of working populations, there can be no social reproduction, which maintains and upholds the legitimacy of the capitalist economic order. Enlightened capitalists, therefore, have a self-interested stake 
in ensuring that workers are housed, clothed and fed and have a minimal level of satisfaction, so they continue to replenish the human stock capitalism uses in the processes of production and accumulation. More specifically, capitalism requires a biopolitics capable of supplying factories, warehouses, office towers and more with a steady flow of fresh, docile labour. The specifically socialdemocratic variation of this theory postulates that the welfare state demands replenishment of the population not merely through labour power-though this is included-but also through taxpayers and, more broadly, 'prosocial' citizens willing and able to enter into the relationships of mutuality that undergird universalist welfarism.

\section{Productive Reproduction: The Conservative Party}

The idea that the demographic forces threaten the Norwegian welfare state stretches back to the 1990s. At the century's end, third-way social democrats believed that low fertility combined with aging populations_or the 'elderly wave' (eldrebølgen), as it became known in public discourse-would undermine central pillars of the welfare state such as generous retirement provisions and other social protections and lead to shortages in labour-intensive sectors such as the public healthcare system. This widespread fear, driven by perceptions of demographic inevitability, resulted in a major overhaul of Norway's state pension system. In 2011, the so-called Pension Reform (Pensjonsreformen) effectively reduced pension payments to lighten a fiscal burden made heavier by a series of governments unwilling to raise income taxes.

It was against this backdrop that Conservative Party Prime Minister Solberg took to the podium on the first day of 2019 to address the Norwegian people:

\footnotetext{
In the past, it was your family that took care of you when you were old. Now, the local authorities and the health service are becoming increasingly important. But the solidarity between generations is still the same. The wheels of our society keep turning because adults look after children. And those who are able to work ensure that the elderly can be cared for. In the coming decades, we will encounter problems with this model. Norwegians are having fewer children. (Solberg, 2019)
}

Before linking the prime minister's neoliberal framings more closely to Foucault, we can use Hannah Arendt's (1998) work on the tripartite unity of labour, work and action. Arendt (1998, p. 8) stated that 'Labor [en]sures not only individual survival but [also] the life of the species. Work and its product, the human artefact, bestow a measure of permanence and durability upon the futility of mortal life and the fleeting character of human time'. However metaphysical 
Arendt's statement might seem, Solberg's speech highlights the intimate, antagonistic relationships among the individual, the welfare state and labour: too little or too much labour or people might threaten to undermine the entire system of which the people, state and labour are part. Labour, in Solberg's speech, ensures the survival of not only the species but also the welfare state. Labour and continual, correct reproductive metrics ensure a measure of permanence for the welfare state and endow the nation state with a certain durable quality. 'Labor and work, as well as action, are also rooted in natality in so far as they have the task of providing and preserve the world for, to foresee and reckon with, the constant influx of newcomers who are born into the world as strangers' (Arendt, 1998, p. 9). Arendt's statement is especially telling as Solberg's speech does speak about how labour and work are rooted in reproduction. Solberg's (2019) claim that 'we all need to have on average, a little over two children' to maintain the current population signals that reproduction is the bedrock upon which all (non-automated) production rests.

Another interesting biopolitical link lies in Solberg's notions of 'generational solidarity' and a 'sustainable welfare state'. Arendt (1998) stated that labour and work are rooted in natality as these universal, fundamental human activities ensure that the current generation can predict a constant flow of children. However, Solberg's biopolitical anxieties emerge as this flow might not be constant, as Arendt so poetically shows. The biopolitical calculus of the birth rate, workforce size, elderly population needing state care and pensions and, finally, mortality rate might be at an unsustainable level for the welfare state.

Liberal and (later) neoliberal governments see the 'problem of the population' (Foucault, 2007, p. 351) as a central issue, which can be related to metrics such as population size, birth rates, docile bodies and mortality rates (Foucault, 2007). However, in the liberal and (now) neoliberal state for which Solberg is a spokesperson, the population also becomes related to wages, prices and work possibilities (Foucault, 2007). This calculus enmeshes wealth and populations, moving, transforming, increasing and diminishing them (Foucault, 2007). The current moment seems to have applied Foucault's (2007) concern with an optimisation of the population as the state and the individual have aligned their interests to reach an ideal level of reproduction and production suited to producing optimal levels of surplus value.

In light of these insights, Solberg's conservatism has a specifically socialdemocratic flavour. Given its pro-market inclinations, though, it also promotes a hollow biopolitics, bereft of the traditional instruments of the Fordist-Keynesian welfare state: generous social spending, massive infrastructure projects, 
nationalised industry, high marginal tax rates to redistribute income and wealth and inheritance taxes to prevent the formation of extremely wealthy intergenerational dynasties. What remains is largely rhetorical sermonising: exhortations to do better aimed at the individual ('Norway needs more children!'). There is little or no discussion on interventions in the housing and labour market, even though some of the fundamental constraints on fertility rates spring from what Giddens (1990, p. 92) termed 'ontological insecurity', ${ }^{4}$ which has only risen with flexibilised labour relations and upwardly spiralling housing costs. Both of these major structural factors, which interact to prevent the formation of childrearing families, are crucial to the formation of fertility rates at sub-replacement levels in Norway and across the Western world. However, the Conservative Party agenda largely precludes any consolidated decommodifying interventions into the economic life of ordinary citizens. The structural and political instruments capable of redressing demographic problems are excluded at the level of ideology.

\title{
Ethnonationalist Anxiety: The Progress Party
}

Not all children born have equal worth. Former Minister of Justice Per Willy Amundsen noted:

\begin{abstract}
I am interested in us having a population composition that is sustainable. Ethnic Norwegians have a declining birth rate. Prime Minister Erna Solberg and I agree that we have to do something about this. But the solution is not a larger immigration population. On the contrary, we have to make sure that the ethnic Norwegian population is maintained. I am very concerned that an increase in child benefits not become a hindrance to integration efforts. [Child benefits] will become a hindrance to integration efforts if we reward immigrants who have a fourth, fifth or sixth child. (Jensen, 2019)
\end{abstract}

Amundsen's remarks recall similar pronatalist, racialising, individually responsibilising tropes found in other ethno-racially charged contexts. For instance, one Israeli human rights activist noted that elements in Israeli society are 'afraid of the Muslim womb', and some Israeli politicians view Palestinian and Israeli Arab populations as a 'demographic threat' (Nurit Peled-Elhanan, n.d.). Similarly, in apartheid South Africa, the state adopted demographic policies 'explicitly designed to prevent ... racial "swamping" of the minority by

4 Giddens (1990, p. 92) defines ontological insecurity as 'the confidence that most humans beings have in the continuity of their self-identity and in the constancy of the surrounding social and material environments of action'. 
the majority population', including encouraging 'nonblack' immigration to South Africa and urging South African white women to bear more children (ChimereDan, 1993, p. 32). Racialised anxieties over allegedly excessive fecundity were also mobilised in the run-up to the Bosnian War in the early 1990s. Bosnian Serb general Ratko Mladic "considered that the greatest danger to Bosnian Serbs was the Muslim "demographic bomb", meaning a Muslim population explosion' and claimed that 'Muslim women were 'production machines, each with ten or twelve children' (O'Ballance, 1995, p. 197). These sentiments fed into the genocidal, anti-Muslim RAM Plan, a military strategic document implemented by Serbian President Slobodan Milošević to 'aim our action at the point where the religious and social structure is most fragile. We refer to the women, especially adolescents, and to the children' (Tatum, 2010, p. 76).

More peaceably but still dramatically, a key element of the Thatcherite project of individual responsibilisation was to shame 'unwed mothers'. After her tenure as prime minister, Margaret Thatcher claimed that single mothers are so irresponsible that it is 'far better to put these children in the hands of a very good religious organisation, and the mother as well, so that they will be brought up with family values' (British Broadcasting Corporation, 1998). Similarly, at the height of US President Reagan's attack on 'welfare queens', who were supposedly irresponsible black women and mothers, the New York Times (1976) summarised the alleged features of this shadowy figure: 'She has 80 names, 30 addresses, 12 Social Security cards and is collecting veterans' benefits on four non-existent deceased husbands. ... Her tax-free cash income alone is over $\$ 150,000$ '. The political left, Greene (2018) wrote, attacked Reagan for 'stoking white voters' latent racism' with a 'stereotype of a black woman having endless kids and cheating the system'. When the state has failed to provide full employment or uphold living standards, politicians have often turned to women's bodies as favoured targets of moralistic sermonising and biopolitical regulation. Ethno-racialisers and ethnonationalists have a long history of invoking racial anxieties, playing on the notion that fertility lies at the heart of the issue of foreigners overrunning the 'homeland'. Take, for instance, UK Independence Party leader Nigel Farage's infamous 'Breaking Point' Brexit poster, which tarnished European Union membership with the spectre of an endless stream of immigrants.

Amundsen's statement proposes a two-pronged strategy to safeguard the welfare state: (i) incentivise production of more offspring through direct fiscal manipulation; and (ii) extend those incentives only to those conforming to the parameters of his 'ethnically Norwegian' population capable of realising a modest, constrained fertility rate, ideally no more than three children per 
woman. This proposal contrasts, for instance, with far-right Hungarian Prime Minister Viktor Orbán's suggestion, only a month after Amundsen's proposal, that Hungarian women who have four or more children be freed from the burden of paying income taxes. 'In all of Europe, there are fewer and fewer children, and the answer of the West to this is migration', Orbán said (Walker, 2019). 'They want as many migrants to enter as there are missing kids so that the numbers will add up. We Hungarians have a different way of thinking. Instead of just numbers, we want Hungarian children. Migration for us is surrender'. Whereas the Hungarian prime minister wants women to give birth to more than three children as an alternative to immigration, Amundsen seeks to achieve a more modest fertility rate by tacitly penalising ethno-racial minorities seen as excessively fecund. Despite important differences in the details of their proposals, both, in their own ways, use a biopolitical rationale to promote their own ethno-nationalists agenda.

Latent within this logic is the idea that Norway is on its way to having a unsustainable population. Amundsen, for instance, claims that current demographic trends guarantee that 'ethnic Norwegians' will become a minority, destabilising the very sustainability of the welfare state. The use of the term 'sustainable' connects with the concept of carrying capacity in modern ecological theory (see, e.g., Barrett \& Odum, 2000). Amundsen's statements make clear that Norway can only carry so many immigrants before it reaches its maximum carrying capacity. The same logic applies to the number of ethnic Norwegians; the welfare state cannot 'carry' too many immigrants while simultaneously reducing its ethnic Norwegian population.

Amundsen completes his proposal by stating that it will 'primarily affect immigrant families with large families, where the birth rates are high. This is particularly true for Somalis, who are ranked in the top (in terms of birth rates) and have far higher birth rates than ethnic Norwegians have. ... It is primarily ethnic Norwegians that have declining birth rates. The solution is not to maintain high birth rates amongst immigrants by offering them high state sponsored benefits' (Jensen, 2019). Amundsen starkly professes a logic of biopolitical power that can be linked directly to Foucault's (2003) notion that biopower is defined not by the sovereign's ability to take lives but by regulation of the space between life and death. Amundsen's ethno-national biopolitics entails rolling out incentives and disincentives to shape the most intimate dimensions of human life including childbearing. In Amundsen's frame, the decision to intervene in citizens' intimate lives differentiates population segments by ethnic background. Amundsen explicitly predicates his biopolitics on a logic of ethnonationalism. 
While Foucault never directly connected biopolitics to ethnonationalism, he did draw a connection between racism and biopolitics. Foucault (2003) brought biopolitics to bear on racism when he asked what racism 'in fact is' (p. 254). He answered: 'It is primarily a way of introducing a break into the domain of life that is under power's control: the break between what must live and what must die' (Foucault, 2003, p. 254). He further noted that racism has two functions. The first is to fragment, to create caesuras within the biological continuum addressed by biopower' (Foucault, 2003, p. 255). The second function of racism, which has greater relevance to our case study, is to

\begin{abstract}
establish a relationship between my life and the death of the other that is not a military or warlike relationship of confrontation, but a biological-type relationship: 'The more inferior species die out, the more abnormal individuals are eliminated, the fewer degenerates there will be in the species as a whole, and the more I-as species rather than individualcan live, the stronger I will be, the more vigorous I will be. I will be able to proliferate'. (Foucault, 2003, p. 255)
\end{abstract}

Our point is not to directly connect Amundsen's proposal to a racist discourse but to highlight Foucault's (2003) insight that racism or, in our case, ethnonationalism in the service of biopolitics, creates a dimension of (bio)ethnic competition. Amundsen singles out ethnic Norwegians as in danger of becoming a minority while suggesting that declining birth rates among ethnic Norwegians indicate an 'unsustainable' demographic development for Norwegian culture and its welfare state. He thus constructs an ethnonationalism that does not propose killing the Other (as in the Serbian RAM Plan) but seeks to severely curtail the Other. Slightly reformulating Foucault's (2003, p. 255) statement that 'the very fact that you let more die will allow you to live more', Amundsen's proposal suggests that the more 'we' (ethnic Norwegians) give birth, the more sustainable the welfare state is. Conversely, the less the immigrant Others reproduce, the more 'we' (ethnic Norwegians) proliferate. Amundsen's statements are not thanatopolitical, a biopolitics of death and killing of the Other. Instead, they instantiate an ethno-nationalistic biopolitics that manipulates who should give birth, how often they should give birth and who should restrain (supposedly) excessive fertility. His biopolitics is not the 'right to death' but the 'right over birth', proclaimed in a putative defence of the welfare state.

Here, we might also note that the notion of 'the right over birth' can be linked to eugenics and social Darwinism. Social Darwinism postulates that by nature, 'superior races' beat 'inferior races' through competition, and the individuals with the best hereditary material reproduce the most efficiently. Social Darwinism thus can be most easily reconciled with a neoliberalism that focuses on market 
competition and a discourse that does not primarily rely on state interventions. Eugenics, in contrast, is more focused on government policies aimed at selecting those fit for reproduction through social engineering. The former is compatible with neoliberalism, whereas the latter is less obviously so. Amundsen's statement, therefore, can be framed as a biopolitics that explicitly supports state interventions to secure what is perceived as a 'sustainable fertility politics'. His position contrasts with Prime Minister Solberg's more individualising rhetoric of personal responsibility to correct falling birth rates. Taken to their respective logical conclusions, which are not necessarily explicitly expressed in policy, Amundsen's ethnonationalist proposal suggests a eugenic logic, while Solberg's anti-structural, individual responsibilisation programme has a more social Darwinian flavour.

One final insight from Foucault emphasises the gravity of introducing politically targeted birth disincentives. Foucault (2003) stated that 'broadly speaking, racism justifies the death-function in the economy of biopower by appealing to the principle that the death of others make one biologically stronger insofar as one is a member of a race or a population, insofar as one is an element in a unitary living plurality' (p. 258). However, in ethnonational ideologies, thanatopolitics does not necessarily involve the death of the Other; instead, restrictions, confinement and expulsion are laid upon the ethno-racial Other in the name of 'sustainability'. Amundsen's proposal then is an example of how coupling the biopolitics of birth with ethnonationalism produces not the death of the Other, as Foucault's account of racism suggests, but a discourse in which the Other is not born in the first place.

\section{Conservative Christian Ethics: The Christian Democratic Party}

The rise of populist ethnonationalism has reactivated familiar tropes from Norway's history of state Lutheran Christianity. Sylvi Listhaug, a leading figure in the Progress Party, prominently wore a crucifix during her tenure as minister of immigration and justice between 2015 and 2017. When questioned about this unusual display of religiosity in one of Europe's most secularised countries, Listhaug replied: 'The crucifix means a lot to me because it belonged to my grandmother. She received it as a gift from my grandfather when they were engaged' (Fossheim \& Talsnes, 2016).

In November 2018, another prominent Progress Party politician, Christian Tybring-Gjedde, emphasised the central importance of 'our Christian heritage', noting that his party was 'the foremost defender of these values in all policy 
formation. The Christian cultural heritage is the very foundation. It must be defended and retransmitted. At the same time, this means that other belief systems will have to occupy a less prominent place' (Tybring-Gjedde, 2018). Listhaug and Tybring-Gjedde's statements both show, if only anecdotally, how ethnonational politics fuses a symbolic politics of religion and ancestry. Indeed, Tybring-Gjedde ties the need to retransmit a Christian cultural heritage to the issues of links between the older and younger generations and the literal, biological reproduction of Protestant citizens. Connecting Tybring-Gjedde's proposal to the biopolitics of Amundsen's statements on limiting immigrant reproduction while raising the ethnic Norwegian birth rate, this biopolitics of reproduction places a clear stress on increasing the Christian ethnic Norwegian birth rate while reducing the immigrant birth rate. If we take the Progress Party's biopolitics seriously, Tybring-Gjedde's (2018) notion that 'other belief systems will have to occupy a less prominent place' indicates that not only other belief systems but also other ethnic groups will have to occupy less prominent places due to the very drastic biopolitical intervention of limiting their number of children. Restricting immigrants' birth rates certainly will make them less visible and prominent within the demographic panopticon of census data, urban geography and other metrics of population demographics.

As we have alluded, this biopolitics of reproduction does not consist of mastery over the 'right to take life' and perhaps not even the 'right to life'; instead, it occupies a space between life and death, involving governance of who will and will not be born. Reproduction has always been a space where potential life meets death. From the potential for death in labour to the promise of new life symbolised in the child, reproduction and power over reproduction constitute a third space within the biopolitical economy of governmentality.

Another instance of biopolitics arises in Ropstad's statement that 'if you can carry one [child], then you can carry two [children]'. This statement expresses the Christian Democrats' partial opposition to liberal abortion laws, particularly the right to selective or multifetal reduction. Rather than the connection to productivity seen in the prime minister's speech or the ethnonationalism embedded in the Progress Party's proposal to restrict child benefits, Ropstad's statement embeds a conservative Christian ethics within the biopolitics of reproduction. Far from a unique stand within rightist Christian conservatism, this position perhaps more telling partially contrasts with stance of coalition partners such as the Progress Party on the issue of immigrant reproduction. Ropstad's statement drew the ire of pro-choice groups, but his position springs from the Christian Democrats' ideology. It strongly holds that it should be up to individual families to decide how many children they want and that 'very serious 
arguments' should be made 'before the state intervenes' in the freedom of families to make reproductive decisions (Christian Democratic Party of Norway, 2017, p. 22).

Ropstad's statement clearly expresses a biopolitics of 'the right to life'-a conservative Christian mantra-and his party's position logically supports families' right to independently decide how many children they want without state intervention. Immigrants, therefore, should also be accorded this right, a position in clear opposition to the Progress Party's proposal to limit birth rates among immigrant families with four or more children. Ironically, the Christian Democrats' biopolitics-while propounding that families should decide how many children they want and the state should create a supportive environment for families to have as many children as they want-still limits these reproductive choices. Families may choose the number of children they want only within the logic of a conservative Christian biopolitics. The freedom to choose remains only as long as it conforms to the constraints laid down by the party's ideology. Allowing multifetal abortion is a case in point: the autonomy of the family-including, crucially, the female body-is only biopolitically guaranteed so long as it remains within the ambit of a conservative Christian view on the 'right to life'. Just as the Progress Party's biopolitics of ethnonationalism aims to circumscribe the freedom to choose, the Christian Democrats' view on legitimate state interventions forecloses certain reproductive actions while enabling others.

\section{Conclusion}

In recent years, declining birth rates across the post-industrialised world have pointed the attention of social scientists, political leaders and social commentators to the so-called demographic transition, or the movement from high birth and mortality rates to lower mortality and birth rates. One underexplored origin of the formation of what we might call the 'low-birth society' is the neoliberalisation of the political economy since the 1980s. Neoliberalism results in social insecurity; future life-course trajectories grow more uncertain as work becomes flexibilised, housing markets are liberalised, social security deteriorates, and universal welfare goods such as education and healthcare are commodified. In early 2019, these issues made a remarkable return to Norway's political agenda as governing centre-right politicians attempted to reverse the country's turn to low birth rates in recent years. However, Norway's turn to neoliberalism in the political economy and, therefore, the biopolitical domain has not been total. Income inequality remains relatively low, universal welfare goods are still widely available, and the welfare state continues to provide social 
security to the sick, disabled, elderly and unemployed, albeit in a fashion that seems likely to deteriorate under the twin pressures of market efficiency and workfarist discipline.

One unexpected manifestation of these developments is seen in the statistical tables on the declining fertility rates in this northern European country. As stressed in a Statistics Norway report, the country's official statistics agency, one of the most powerful explanations of declining fertility rates in recent years has been 'heightened economic insecurity' (Dommermuth \& Lappegård, 2017, p. 40). Precluded by ideological affiliations from utilising the powerful statecentred tools available to the early social democrats, the centre-right politicians discussed have adopted a series of rhetorical biopolitical postures expressed through producerist moral exhortations, ethnonational exclusion and conservative Christian discourse. As the welfare state has retreated, a form of sermonising biopolitics seems to have surfaced and taken its place.

Amidst this increasingly polarised community, three discoursesbiopolitical producerism, ethnonationalist panic and conservative Christianityhave entered and engaged with one another to fill the vacuum left by Keynesian Fordism. However, the defence of the welfare state in the name of neoliberalism seems likely to fail as only a politics of social democracy can re-create the social democracy for which these politicians seem to both tacitly and overtly long. In short, these physicians of the polity seem to prescribe the wrong cures for a wholly misdiagnosed illness.

\section{Acknowledgements}

The authors would like to thank the anonymous reviewers for their kind, thoughtful and inspiring comments during the review of this article. We would also like to thank the editorial staff at the Nordic Journal of Social Research for their careful and diligent aid with the manuscript, helping us take it from manuscript to article form.

\section{References}

Adorno, T. W. (2000). Introduction to sociology. Stanford, CA: Stanford University Press.

Aftenposten. (2019, January 18). Ropstad—klarer du å bære frem ett barn, klarer du to. [Ropstad: "If you can carry one child, you can carry two."]. Retrieved from https://www.aftenposten.no/norge///OnKOMA/Ropstad--Klarer-du-a-bare-fremett-barn_-klarer-du-to

Arendt, H. (1998). The human condition (2nd ed.). Chicago, IL: University of Chicago Press. https://doi.org/10.7208/chicago/9780226924571.001.0001 
Barrett, G. W., \& Odum, E. P. (2000). The twenty-first century: the world at carrying capacity. BioScience, 50(4), 363-368. https://doi.org/10.1641/00063568(2000)050[0363:TTFCTW]2.3.CO;2

British Broadcasting Corporation. (1998, October 21). Thatcher stirs up single parents. BBC. Retrieved from http://news.bbc.co.uk/2/hi/uk news/197963.stm

Benson, R., \& Neveu, E. (Eds.). (2005). Bourdieu and the journalistic field. Cambridge, UK: Polity Press.

Chimere-Dan, O. (1993). Population policy in South Africa. Studies in Family Planning, 24(1), 31-39. https://doi.org/10.2307/2939212

Christian Democratic Party of Norway. (2017). KrFs stortingsprogram, 2017-2021. [Christian Democratic Party Parliamentary Platform, 2017-2021.] Retrieved from https://www.krf.no/globalassets/vedlegg/politiske-dokumenter/politiskprogram/stortingsprogram-krf-2017-2021.pdf

Dean, M. (2013). The signature of power: sovereignty, governmentality and biopolitics. London, UK: Sage. https://doi.org/10.4135/9781446288313

Dommermuth, L., \& Lappegård, T. (2017). Nedgangen i fruktbarheten fra 2010: betydningen av utdanning, økonomisk aktivitet og økonomiske ressurser for førstefødsler og tredjefødsler. [The decline in fertility from 2010: the meaning of education, economic activity, and economic resources for births of first and third children.] Statistics Norway 2017/12. Retrieved from https://www.ssb.no/befolkning/artikler-og-publikasjoner/nedgangen-ifruktbarheten-fra-2010

Fossheim, K., \& Talsnes, S. (2016, February 6). Åpenhjertig Listhaug一derfor bærer jeg korset. [Candid Listhaug: Here's why I wear a crucifix.] TV2. Retrieved from https://www.tv2.no/a/8013803/

Foucault, M. (1990). The history of sexuality: an introduction (vol. I). Trans. Robert Hurley. New York, NY: Vintage.

Foucault, M. (2003). 'Society must be defended': lectures at the Collège de France, 1975-76. London, UK: Allen Lane.

Foucault, M. (2007). Security, territory, population: lectures at the Collège de France, 1977-78. Houndmills, UK: Palgrave Macmillan.

Foucault, M. (2008). The birth of biopolitics: lectures at the Collège de France, 19781979. Houndmills, UK: Palgrave Macmillan.

Giddens, A. (1990) The consequences of modernity. Stanford, CA: Stanford University Press.

Greene, L. (2018). Talk on the wild side: the untameable nature of language. London, UK: Profile Books.

Jensen, I. (2019, January 10). Vil kutte i barnetrygden for at innvandrere skal få færre barn. [Would like to cut child benefits so that immigrants produce fewer children.] TV2. Retrieved from https://www.tv2.no/a/10335046/

Lemke, T., Casper, M. J., \& Moore, L. J. (2011). Biopolitics: an advanced introduction. New York, NY: New York University Press.

Marx, K. (1976). Capital: a critique of political economy (vol. 1). London, UK: Penguin Books.

New York Times. (1976, February 15). 'Welfare queen' becomes issue in Reagan campaign. Retrieved from https://www.nytimes.com/1976/02/15/archives/welfare-queen-becomes-issue-inreagan-campaign-hitting-a-nerve-now.html. 
Norwitz, E., Edusa, V., \& Park, J. S. (2005). Maternal physiology and complications of multiple pregnancy. Seminars in Perinatology, 29(5), 338-348. https://doi.org/10.1053/j.semperi.2005.08.002

Norsk Telegrambyrå. (2018, November 19). Barnetrygd utgjør mindre av fattiges inntekt. [Child benefits make up smaller portion of the income of the poor.] Dagbladet.no. Retrieved from https://www.dagbladet.no/nyheter/barnetrygd-utgjor-mindre-avfattiges-inntekt/70511394.

O’Ballance, E. (1995) Civil war in Bosnia, 1992-94. London: Macmillan Press. https://doi.org/10.1007/978-1-349-13666-7

Peled-Elhanan, N. (n.d.). The suffering Palestinian women endure every day. Retrieved from http://www.thehypertexts.com/Archive/Nurit\%20Peled-Elhanan.htm.

Shammas, V. L. (2018). The dissolution of social democracy: how law and order came to Norway. Federal Sentencing Reporter, 31(1), 85-89. https://doi.org/10.1525/fsr.2018.31.1.85

Solberg, E. (2019, January 1). New year's address 2019. Retrieved from https://www.regjeringen.no/en/aktuelt/new-years-address-2019/id2623249/

Statistics Norway. (2018, March 6). Rekordlav fruktbarhet. Retrieved from https://www.ssb.no/befolkning/artikler-og-publikasjoner/rekordlav-fruktbarhet

Tatum, D. (2010). Genocide at the dawn of the $21^{\text {st }}$ century: Rwanda, Bosnia, Kosovo, and Darfur. New York, NY: Palgrave Macmillan.

Tybring-Gjedde, C. (2018, November 17). Lite som minner om kristne verdier, KrF. [Little that is reminiscent of Christian values, KrF.] Aftenposten. Retrieved from https://www.aftenposten.no/meninger/debatt/i/G19BxJ/Lite-som-minner-omkristne-verdier_-KrF--Christian-Tybring-Gjedde-Frp

Walker, S. (2019, February 10). Viktor Orbán: no tax for Hungarian women with four or more children. The Guardian. Retrieved from https://www.theguardian.com/world/2019/feb/10/viktor-orban-no-tax-forhungarian-women-with-four-or-more-children 